\title{
Blue Light Emission from Cyclometallated Iridium (III) Cyano Complexes: Syntheses, Crystal Structures, and Photophysical Properties
}

\author{
Robert D. Sanner and Nerine J. Cherepy* \\ Lawrence Livermore National Laboratory, Livermore, CA 94550 \\ Victor G. Young, Jr. \\ Department of Chemistry, University of Minnesota, Minneapolis, MN 55455
}

\begin{abstract}
We describe the synthesis and crystal structures of four iridium compounds containing the 2-(4,6-difluorophenyl)pyridyl ligand. Cleavage of dichloro-bridged iridium (III) dimers with phosphorus ligands leads to (46dfppy) $)_{2} \operatorname{Ir}(\mathrm{L})(\mathrm{Cl})$ where $\mathrm{L}=\mathrm{PPh}_{3}$ or $\mathrm{P}(\mathrm{OPh})_{3}$. Treatment of the chloro compounds with cyanide forms the cyano complexes (46dfppy) $)_{2} \operatorname{Ir}(\mathrm{L})(\mathrm{CN})$. All complexes exhibit a trans effect in their molecular structures due to the phosphorus ligands, with the phosphite having a greater effect than the phosphine. With $\mathrm{L}=\mathrm{PPh}_{3}$, blue photoluminescence with CIE coordinates $(\mathrm{x}=0.16, \mathrm{y}=0.24)$, quantum yield of $0.66 \pm 0.15$ and $4.5 \pm 0.5$ microsecond decay time is measured. For $\mathrm{L}=\mathrm{P}(\mathrm{OPh})_{3}$, blue photoluminescence with CIE coordinates ( $x=0.16, y=0.21)$, quantum yield of $0.65 \pm 0.15$ and $2.9 \pm 0.3$ microsecond decay time is measured.
\end{abstract}

Keywords: Blue phosphorescence; Iridium complexes; metallorganic light emitters

*Corresponding author.

E-mail address: cherepy1@llnl.gov

Telephone: 925-424-3492

FAX: 925-423-6394 


\section{Introduction}

Cyclometalated iridium(III) complexes have been investigated in recent years as emitters for organic light-emitting diodes (OLEDs). ${ }^{1}$ A common cyclometalating ligand is the 2-phenylpyridyl moiety (ppy) which has shown its usefulness in a host of compounds with widely varying emission characteristics. Representative examples display emission across the visible spectrum including red, ${ }^{2}$ orange, ${ }^{3}$ green, ${ }^{4}$ and blue. ${ }^{5}$

To obtain the highest light yields in OLEDs $^{6}$ or in plastic scintillators, ${ }^{7}$ at low doping levels, the lowest-lying triplet state of the iridium complex must lie at lower energy than the host. For example, $\mathrm{N}, \mathrm{N}^{\prime}$-dicarbazolyl-3,5-benzene $\left(\mathrm{mCP}, \mathrm{T}_{1}=2.9 \mathrm{eV}\right)$ offers excellent efficiency with the best known blue-green iridium complex, bis[2-(4,6-difluorophenyl) pyridinato-C2,N](picolinato)iridium, $\operatorname{Ir}(46 \mathrm{dfppy})_{2}\left(\right.$ pic), or FIrpic $\left(\mathrm{T}_{1}=2.7 \mathrm{eV}\right)$, at doping levels of $\sim 1 \%{ }^{8}$ A variety of deeper blue-emitting Iridium complexes have been reported, many with modest quantum yields, and some have limited stability under operating conditions in OLED devices. $., 6,8-13$ For these reasons, alternative blue phosphorescent emitters, in particular, blue emitters with low-lying $\mathrm{T}_{1}$ states for use in the full range of hosts, are of interest.

We have sought to prepare compounds with emission in the deep blue which can be realized by maximizing the HOMO-LUMO energy gap of the complex. Our approach is to focus on lowering the energy of the predominantly metal-centered $t_{2 g} \mathrm{HOMO}$ while leaving the ligand-centered LUMO relatively unchanged. Thus, strong field electron-withdrawing ancillary ligands such as triphenylphosphine and cyanide merit investigation. ${ }^{14-18}$ In addition to ancillary ligand effects, substitution of the phenyl hydrogens on the phenylpyridine group has been shown to influence the HOMO-LUMO gap. The use of electron-withdrawing fluorine atoms, particularly at the 4 and 6 positions, stabilizes the HOMO more than the LUMO and causes a blue shift in emission. ${ }^{19,20}$ Prior workers have reported the use of the difluorophenylpyridyl ligand with an ancillary phosphine ligand as in $\operatorname{Ir}(46 \mathrm{dfppy})_{2}\left(\mathrm{PPh}_{3}\right)(\mathrm{L})$, where 46dfppy=2-(4,6-difluorophenyl)pyridyl and $\mathrm{L}=\left(\mathrm{NCS}^{-}\right)$or $\left(\mathrm{NCO}^{-}\right) .{ }^{10}$ Also, phosphine complexes using nonfluorinated phenylpyridine ligands are known, as in $\operatorname{Ir}(\text { ppy })_{2}\left(\mathrm{PPh}_{3}\right)(\mathrm{L})$, where $\mathrm{L}=\left(\mathrm{NCS}^{-}\right),\left(\mathrm{N}_{3}{ }^{-}\right)$, or $\left(\mathrm{NCO}^{-}\right)^{20}$ and $\operatorname{Ir}(\mathrm{ppy})_{2}(\mathrm{~L})(\mathrm{CN})$, where $\mathrm{L}=\mathrm{PPh}_{3}, \mathrm{P}(n-\mathrm{Bu})_{3}$, or $\mathrm{P}(\mathrm{OPh})_{3}{ }^{21}$ We report herein the synthesis, $\mathrm{x}$-ray structural characterization, and electronic spectroscopy of four compounds: (46dfppy) ${ }_{2} \operatorname{Ir}\left(\mathrm{PPh}_{3}\right)(\mathrm{X})$ and (46dfppy $)_{2} \operatorname{Ir}\left[\mathrm{P}(\mathrm{OPh})_{3}\right](\mathrm{X})$, where $\mathrm{X}=\left(\mathrm{Cl}^{-}\right)$or $\left(\mathrm{CN}^{-}\right)$. We examine the differences in the steric and electronic properties of the two phosphorus ligands $\mathrm{s}^{22}$ and their influence on the structures and emission spectra of the complexes. 


\section{Results and Discussion}

Scheme 1. Synthetic procedures

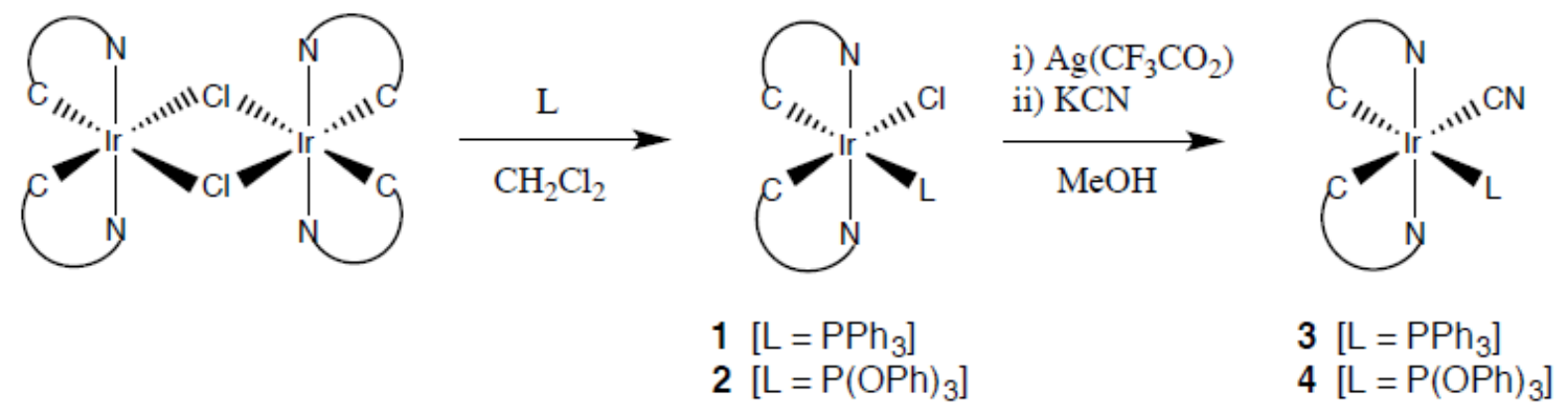

Synthesis and Structure. The reaction sequence is depicted in Scheme 1. Thus, cyclometalated dichloro-bridged iridium dimer $\left[(46 \mathrm{dfppy})_{2} \mathrm{Ir}(\mathrm{Cl})\right]_{2}$ was smoothly cleaved by phosphine or phosphite ligands in methylene chloride to yield the chloro monomers $\operatorname{Ir}(46 \text { dfppy })_{2}(\mathrm{~L})(\mathrm{Cl})$, where $\mathrm{L}=\mathrm{PPh}_{3}(\mathbf{1})^{10}$ or $\mathrm{P}(\mathrm{OPh})_{3}(\mathbf{2})$. The trans- $\mathrm{N}, \mathrm{N}$ and cis-C,C bonding of the difluorophenylpyridine ligands about the iridium center is maintained upon addition of the monodentate phosphorus ligand (vide infra). Treatment of these chloro monomers with silver trifluoroacetate in methanol followed by potassium cyanide leads to replacement of the chloride ligand to form the cyano complexes $\operatorname{Ir}(46 \mathrm{dfppy})_{2}(\mathrm{~L})(\mathrm{CN})$, where $\mathrm{L}=\mathrm{PPh}_{3}(3)$ or $\mathrm{P}(\mathrm{OPh})_{3}(4)$, again with retention of geometry about the iridium. The chemical structures for the compounds under discussion are shown in Figure 1.
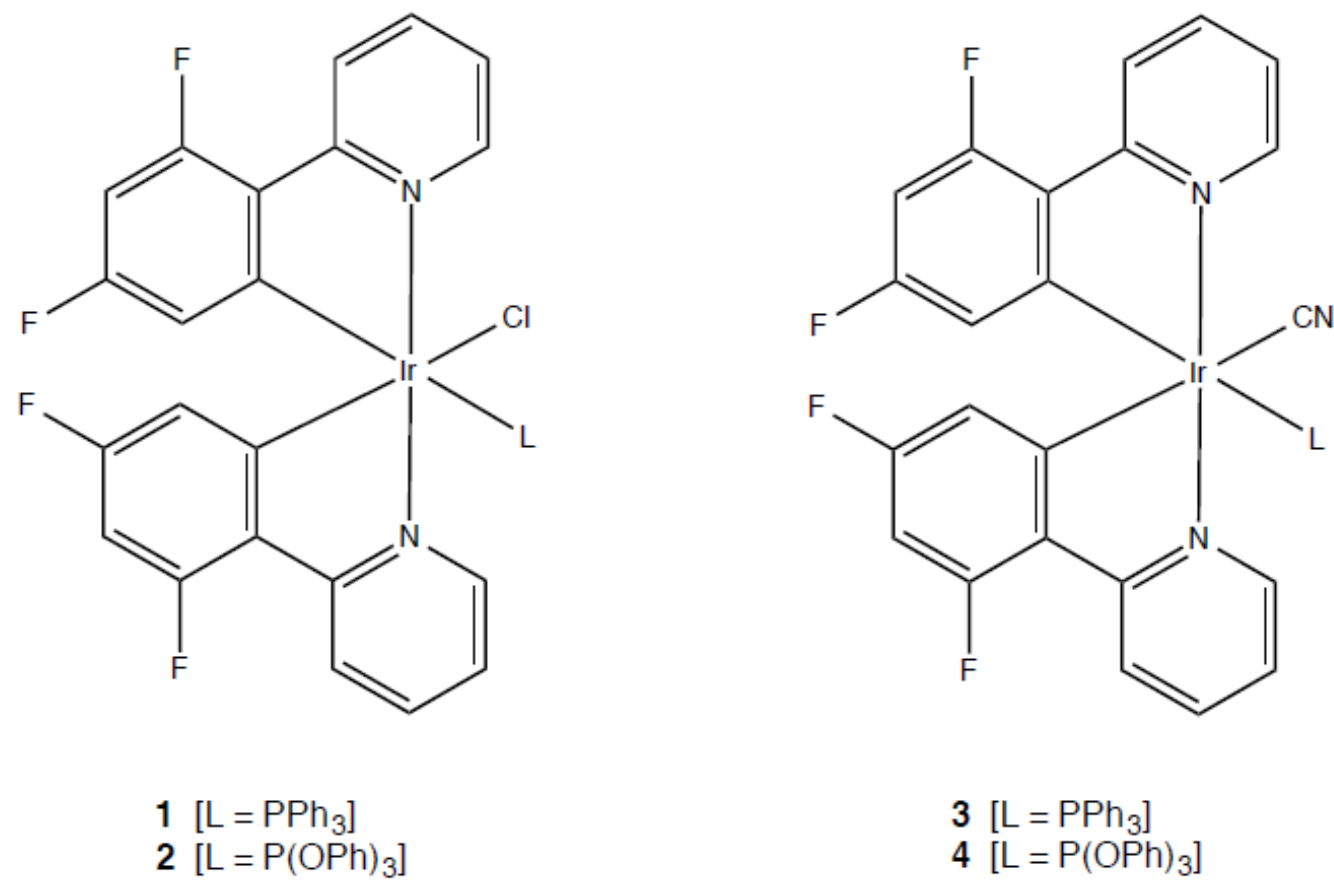

$$
2\left[\mathrm{~L}=\mathrm{P}(\mathrm{OPh})_{3}\right]
$$$$
3\left[\mathrm{~L}=\mathrm{PPh}_{3}\right]
$$$$
4\left[\mathrm{~L}=\mathrm{P}(\mathrm{OPh})_{3}\right]
$$

Figure 1. Chemical structures of compounds 1, 2, 3 and 4. 
The molecular structures of compounds 1-4 have been confirmed by x-ray crystallography and ORTEP diagrams of these complexes are shown in Figures 2-5; crystal and structure refinement data are provided in Table 1 . All of the complexes exhibit the same distorted octahedral geometry: the pyridyl nitrogen atoms of the 46dfppy ligands are trans to each other while the phenyl carbon atoms bound to the iridium are cis. The phosphorus ligand and anionic ligand $\left(\mathrm{Cl}^{-}\right.$or $\left.\mathrm{CN}^{-}\right)$are both mutually cis to the pyridyl nitrogens as well as cis to each other. The octahedral symmetry around the iridium atom is distorted in that the non-phosphorus ligands are pushed away from the phosphorus ligands presumably due to steric factors. Thus the N-Ir-N bond angles (ideally $180^{\circ}$ ) are collapsed in all complexes, ranging from $167^{\circ}-168^{\circ}$. In the chloride complexes the $\mathrm{Cl}-\mathrm{Ir}-\mathrm{C}$ bond angles are collapsed somewhat $\left(172^{\circ}\right.$ and $\left.174^{\circ}\right)$ while in the cyanide complexes the $\mathrm{C}$ Ir-C(N) angles are $171^{\circ}$ and $174^{\circ}$. The phenyl and pyridine rings in each 46dfppy ligand are slightly twisted with respect to each other across the $\mathrm{C}-\mathrm{C}$ bond linking the two rings. The dihedral angle between best planes for the two rings averages $5^{\circ}$ in 1,2 , and 4 and $7.5^{\circ}$ in 3 . There is a pronounced trans effect due to the phosphorus ligand. Thus, in $\mathbf{1}$, the Ir-C bond length trans to the phosphine is $0.036 \AA$ Aonger than the Ir-C bond trans to the chloride. The difference in $\mathbf{2}$ is even more pronounced with an elongation of $0.054 \AA$ for the bond trans to the phosphite. This is in accord with Tolman's substituent effect parameter, ${ }^{23}$ which is larger for $\mathrm{OPh}$ (9.7) compared to $\mathrm{Ph}$ (4.3) and is representative of the electronic effect of phosphorus ligands. For compounds $\mathbf{3}$ and $\mathbf{4}$ we are comparing Ir-C bond lengths trans to phosphorus and cyanide ligands. In 3 , the Ir-C bond length trans to the phosphine is $0.016 \AA$ longer than the Ir-C bond trans to the cyanide while in $\mathbf{4}$ the elongation for phosphite vs. cyanide is $0.021 \AA$. Note that the trans effect for the phosphorus ligand in the chloride complexes is more pronounced than in the cyanide complexes. This is reflective of the strong field cyanide ligand exerting its own trans effect in $\mathbf{3}$ and $\mathbf{4}$. The iridiumphosphorus bonding can be compared directly by looking at the relevant bond lengths. Thus, the Ir-P bond in $\mathbf{2}$ (phosphite) is 0.14 A shorter than in $\mathbf{1}$ (phosphine) while the same bond in 4 is $0.11 \AA$ shorter than in 3 . While we cannot rule out steric factors due to the larger cone angle 18 of the phosphine $\left(145^{\circ}\right)$ compared to the phosphite $\left(128^{\circ}\right)$ (which would tend to elongate the Ir-phosphine bond), this data suggests at least some contribution from electronic factors resulting in reduced Ir-P bond lengths in phosphite ( 2 and $\mathbf{4}$ ) compared to phosphine ( $\mathbf{1}$ and $\mathbf{3}$ ) complexes. Two of the structures in this set have important crystallographic features to note. First, 1 crystallizes in space group $P 2_{1} / n$ with two molecules in the asymmetric unit $\left(\mathrm{Z}=8, \mathrm{Z}^{\prime}=2\right)$. The centers of mass for both molecules are aligned along the $c$-axis in the same relative conformation. This suggests the structure could become modulated at some other temperature or could simplify to a related $P 2_{1} / n$ $Z^{\prime}=1$ structure at some elevated temperature. Second, $\mathbf{3}$ is a triple-solvate of methanol where all three solvent molecules are concatenated through hydrogen bonds originating on the cyanide nitrogen acceptor. The non-hydrogen atoms of the methanol solvent refined poorly such that $\mathrm{C}-\mathrm{O}$ bond distances were restrained and these six atoms were refined with isotropic displacement parameters. 


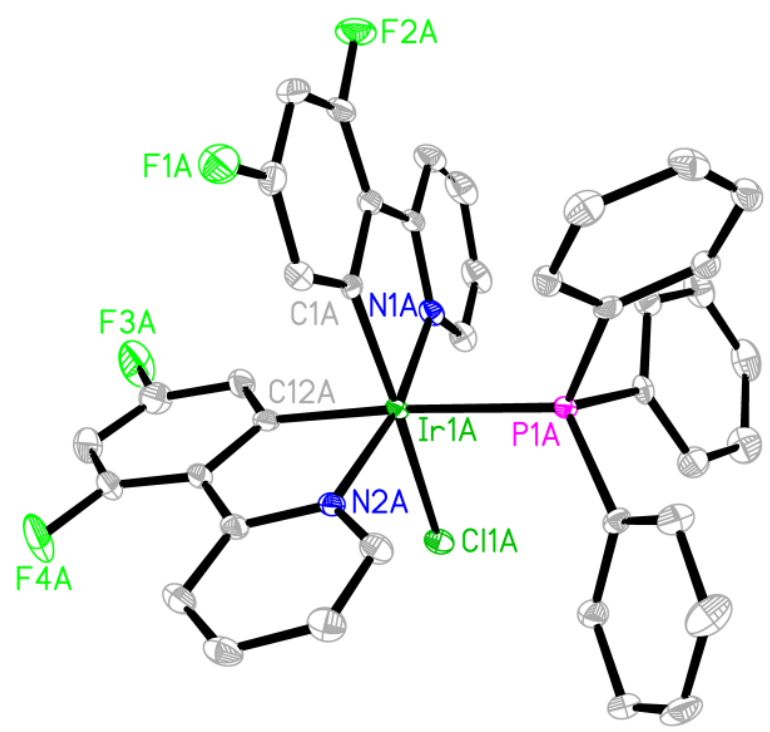

Figure 2. Thermal ellipsoid drawing of $1 \mathbf{a}$ is presented at the $50 \%$ probability level with the hydrogen atoms omitted for clarity. Two molecules are found in the asymmetric unit; only molecule $\mathbf{A}$ is shown in the figure. Selected bond distances $(\AA)$ and bond angles $\left({ }^{\circ}\right)$ for $1 \mathbf{a}$ : $\operatorname{Ir} 1 \mathrm{~A}$ C1A 2.008(3), Ir1A-N1A 2.043(2), Ir1A-C12A 2.044(3), Ir1A-N2A 2.067(2), Ir1A-P1A 2.4415(6), Ir1A-Cl1A 2.4726(7), N1A-Ir1A-N2A 169.03(9), C12A-Ir1A-P1A 174.79(8), and C1A-Ir1A-Cl1A 172.31(8); for 1b: Ir1B-C1B 2.009(3), Ir1B-C12B 2.039(3), Ir1B-N1B 2.043(2), Ir1B-N2B 2.065(2), Ir1B-P1B 2.4293(6), Ir1B-Cl1B 2.4642(7), N1B-Ir1B-N2B 168.25(9), C12B-Ir1B-P1B 174.48(8), and C1B-Ir1B-Cl1B 171.48(8). 


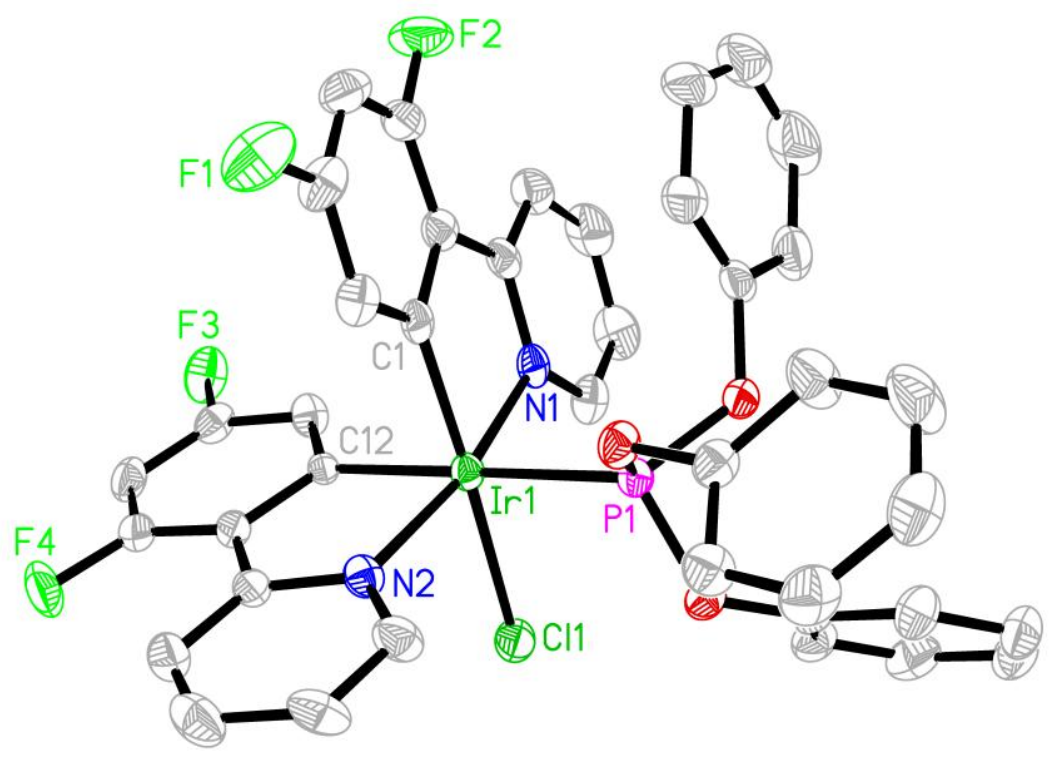

Figure 3. Thermal ellipsoid drawing of 2 is presented at the $50 \%$ probability level with the hydrogen atoms omitted for clarity. Selected bond distances $(\AA)$ and bond angles $\left({ }^{\circ}\right)$ for 2:Ir1-C1 2.005(4), Ir1-N1 2.050(3), Ir1-C12 2.059(3), Ir1-N2 2.065(3), Ir1-P1 2.2979(9), Ir1-Cl1 2.4587(9), N1-Ir1-N2 168.44(11), C12-Ir1-P1 178.13(10), and C1-Ir1-Cl1 174.03(10).

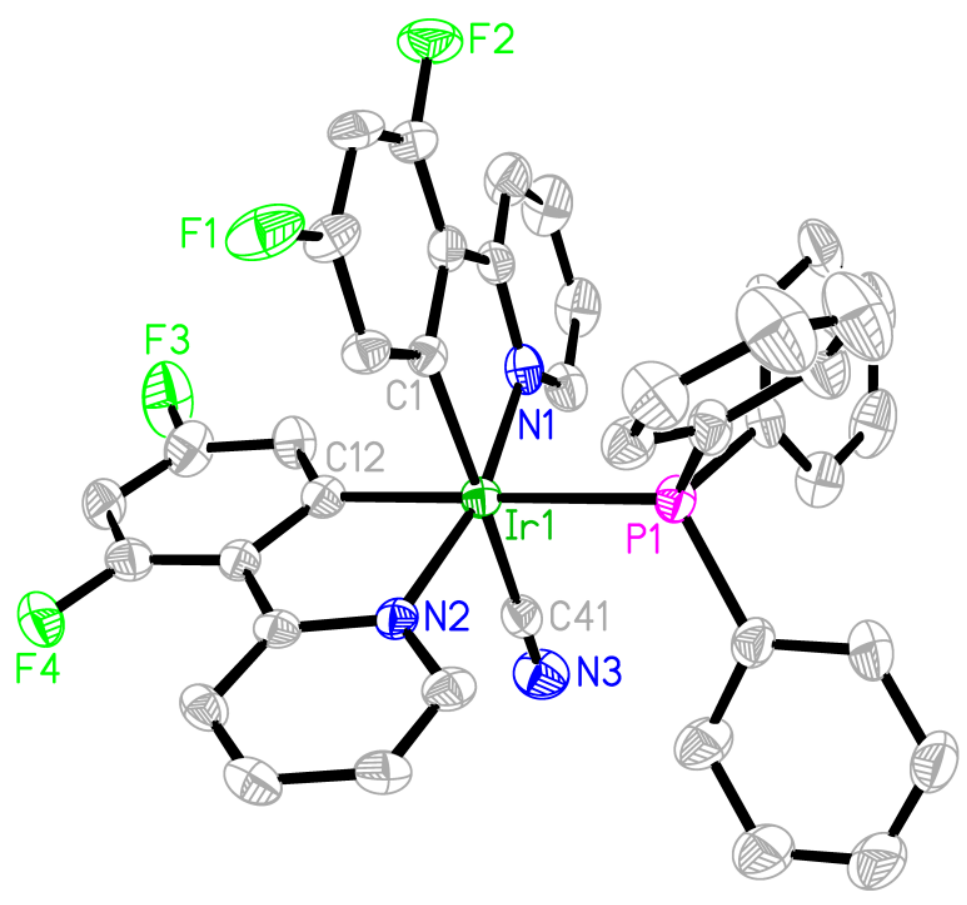

Figure 4. Thermal ellipsoid drawing of $3 \cdot 3\left(\mathbf{C H}_{3} \mathbf{O H}\right)$ is presented at the $50 \%$ probability level with the hydrogen atoms and three methanol solvate molecules omitted for clarity. Selected bond distances $(\AA)$ and bond angles $\left(^{\circ}\right)$ for 3: Ir1-C12 2.039(5), Ir1-C41 2.048(6), Ir1-C1 2.055(5), Ir1-N1 2.058(5), Ir1-N2 2.068(4), Ir1-P1 2.4039(14), C41-Ir1-C1 171.3(2), N1-Ir1-N2 167.09(17), and C12-Ir1-P1 179.47(16). 


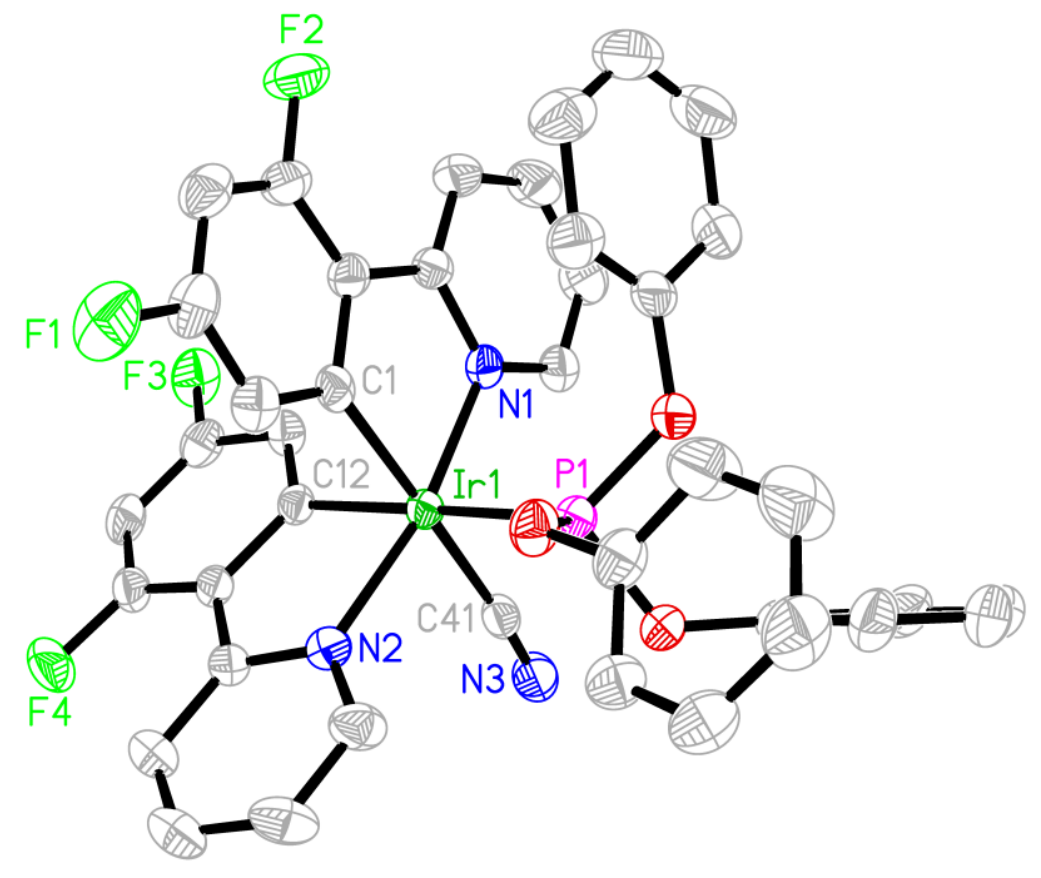

Figure 5. Thermal ellipsoid drawing of 4 is presented at the 50\% probability level with the hydrogen atoms omitted for clarity. Selected bond distances $(\AA)$ and bond angles $\left({ }^{\circ}\right)$ for 4: $\operatorname{Ir} 1$ C1 2.043(3), Ir1-N1 2.051(2), Ir1-C41 2.054(3), Ir1-C12 2.064(3), Ir1-N2 2.070(2), Ir1-P1 2.2924(7), C1-Ir1-C41 173.88(11), N1-Ir1-N2.167.61(9), and C12-Ir1-P1 178.28(8). 
Table 1. Crystal data and structure refinem ent data for $1,2,3$, and 4 .

\begin{tabular}{|c|c|c|c|c|}
\hline Identification code & 1 & 2 & $3 \cdot 3\left(\mathrm{CH}_{3} \mathrm{OH}\right)$ & 4 \\
\hline Empirical formula & $\mathrm{C}_{40} \mathrm{HH}_{27} \mathrm{ClF}_{4} \mathrm{IrN}_{2} \mathrm{P}$ & $\mathrm{C}_{40} \mathrm{H}_{27} \mathrm{ClF}_{4} \mathrm{IrN}_{2} \mathrm{O}_{3} \mathrm{P}$ & $\mathrm{C}_{44} \mathrm{H}_{39} \mathrm{~F}_{4} \mathrm{IrN}_{3} \mathrm{O}_{3} \mathrm{P}$ & $\mathrm{C}_{41} \mathrm{H}_{2} 7 \mathrm{~F}_{4} \mathrm{IrN}_{3} \mathrm{O}_{3} \mathrm{P}$ \\
\hline Formula weight & 870.25 & 918.25 & 956.95 & 908.82 \\
\hline Temperature & $123(2) \mathrm{K}$ & $173(2) \mathrm{K}$ & $123(2) \mathrm{K}$ & $173(2) \mathrm{K}$ \\
\hline Wavelength & $1.54178 \AA$ & $0.71073 \AA$ & $0.71073 \AA$ & $1.54178 \AA$ \\
\hline Crystal system & Monoclinic & Triclinic & Monoclinic & Triclinic \\
\hline Space group & $\mathbf{P} 2 / \mathrm{n}$ & PI & $\mathbf{P} 2 \mathrm{l} / \mathbf{n}$ & $\mathrm{PI}$ \\
\hline \multirow[t]{6}{*}{ Unit cell dimensions } & $a=10.5528(3) \AA$ & $a=10.3770(9) \AA$ & $a=13.359(1) \AA$ & $a=10.3157(2) \AA$ \\
\hline & $b=31.4059(8) \AA$ & $b=11.5597(10) \AA$ & $b=14.9094(11) \AA$ & $b=11.5341(3) \AA$ \\
\hline & $c=19.6541(5) \AA$ & $c=14.6959(12) \AA$ & $c=20.1848(15) \AA$ & $c=14.7501(4) \AA$ \\
\hline & $\alpha=90^{\circ}$ & $\alpha=98.595(1)^{\circ}$ & $\alpha=90^{\circ}$ & $\alpha=98.0470(16)^{\circ}$ \\
\hline & $\beta=94.945(1)^{\circ}$ & $\beta=91.502(1)^{\circ}$ & $\beta=103.552(1)^{\circ}$ & $\beta=91.5289(17)^{\circ}$ \\
\hline & $\gamma=90^{\circ}$ & $\gamma=100.344(1)^{\circ}$ & $\gamma=90^{\circ}$ & $\gamma=99.6871(15)^{\circ}$ \\
\hline Volume & $6489.5(3) \AA^{3}$ & $1712.2(3) \AA^{3}$ & $3908.4(5) \AA^{3}$ & $1710.67(7) \AA^{3}$ \\
\hline$Z, Z^{\prime}$ & 8,2 & 2,1 & 4,1 & 2,1 \\
\hline Density (calculated) & $1.781 \mathrm{Mg} / \mathrm{m}^{3}$ & $1.781 \mathrm{Mg} / \mathrm{m}^{3}$ & $1.626 \mathrm{Mg} / \mathrm{m}^{3}$ & $1.764 \mathrm{Mg} / \mathrm{m}^{3}$ \\
\hline Absorption coefficient & $9.674 \mathrm{~mm}^{-1}$ & $4.089 \mathrm{~mm}^{-1}$ & $3.521 \mathrm{~mm}^{-1}$ & $8.582 \mathrm{~mm}^{-1}$ \\
\hline$F(000)$ & 3408 & 900 & 1904 & 892 \\
\hline Crystal color, morphology & Y ellow, Plate & Yellow, Plate & Yellow, Block & Yellow, Prism \\
\hline Crystal size & $0.30 \times 0.20 \times 0.10 \mathrm{~mm}^{3}$ & $0.35 \times 0.22 \times 0.08 \mathrm{~mm}^{3}$ & $0.35 \times 0.25 \times 0.18 \mathrm{~mm}^{3}$ & $0.12 \times 0.05 \times 0.05 \mathrm{~mm}^{3}$ \\
\hline$\theta$ range & 2.659 to $74.565^{\circ}$ & 1.813 to $27.593^{\circ}$ & 1.715 to $27.479^{\circ}$ & 3.030 to $68.341^{\circ}$ \\
\hline Reflections collected & 81498 & 20305 & 45277 & 22361 \\
\hline Independent reflections & $13061\left[R_{\text {int }}=0.0630\right]$ & $7827\left[R_{\mathrm{int}}=0.0463\right]$ & $8951\left[R_{\text {int }}=0.0672\right]$ & $6158\left[R_{\text {int }}=0.0326\right]$ \\
\hline Observed reflections & 10681 & 6706 & 6750 & 5688 \\
\hline Completeness & $99.5 \%$ & $99.8 \%$ & $100.0 \%$ & $98.8 \%$ \\
\hline Absorption correction & Multi-scan & Multi-scan & Multi-scan & Multi-scan \\
\hline Max. and min transmission & 0.2478 and 0.1129 & 0.7356 and 0.3287 & 0.5698 and 0.3721 & 0.5468 and 0.1531 \\
\hline Data / restraints / parameters & $13061 / 0 / 883$ & $7827 / 0 / 469$ & $8951 / 3 / 475$ & $6158 / 0 / 478$ \\
\hline G oodness-of-fit on $F^{2}$ & 1.017 & 1.021 & 1.021 & 1.039 \\
\hline Final $R$ indices $[1>2 \sigma(I)]$ & $R 1=0.0226, w R 2=0.0470$ & $R 1=0.0315, w R 2=0.0555$ & $R 1=0.0415, w R 2=0.0993$ & $R 1=0.0209, w R 2=0.0475$ \\
\hline$R$ indices (all data) & $R 1=0.0340, w R 2=0.0503$ & $R 1=0.0402, w R 2=0.0589$ & $R 1=0.0623, w R 2=0.1095$ & $R 1=0.0245, w R 2=0.0488$ \\
\hline Largest diff. peak and hole & 0.851 and -0.742 e. $\AA^{-3}$ & 1.196 and -0.728 e. $\AA^{-3}$ & 1.555 and -1.126 e. $\AA^{-3}$ & 0.921 and $-0.508 \mathrm{e} . \AA^{-3}$ \\
\hline
\end{tabular}


Spectroscopy. The UV-visible electronic absorption spectra of iridium complexes 3, 4 and FIrpic in $\mathrm{CH}_{2} \mathrm{Cl}_{2}$ solution (Figure 6 and Table 2) are dominated by an intense absorption band at $\sim 260 \mathrm{~nm}\left(\varepsilon=30-40 \times 10^{3} \mathrm{M}^{-1} \mathrm{~cm}^{-1}\right)$ assigned to spin-allowed ligand centered (LC) ${ }^{1}\left(\pi-\pi^{*}\right)$ transitions on the cyclometallated ligand. The weaker bands at lower energies (300-440 nm) have charge-transfer (CT) character related to electronic transitions from the metal center to the cyclometallated ligands (MLCT). The absorption spectra shown in Figure 6 suggest that the ${ }^{1}$ MLCT state lies at $413 \mathrm{~nm}(3)$ or $409 \mathrm{~nm}(4)$, while the ${ }^{3} \mathrm{MLCT}$ state lies at $441 \mathrm{~nm}(3)$ or $437 \mathrm{~nm}$ (4). These bands exhibit very low relative absorption, and reveal higher lying $\mathrm{T}_{1}$ states for these complexes, compared to the $455 \mathrm{~nm}$ band of FIrpic. This is presumably due to the substitution of the picolinate ligand in FIrpic by the stronger field cyano and phosphine (compound $\mathbf{3}$ ) or phosphite (compound 4) ligands. These stronger field ligands stabilize the metal-centered HOMO. In addition, the phosphite causes a slightly larger blue shift of the absorption bands than the phosphine as could be predicted from the electronic effects shown in the molecular structure (vide supra).

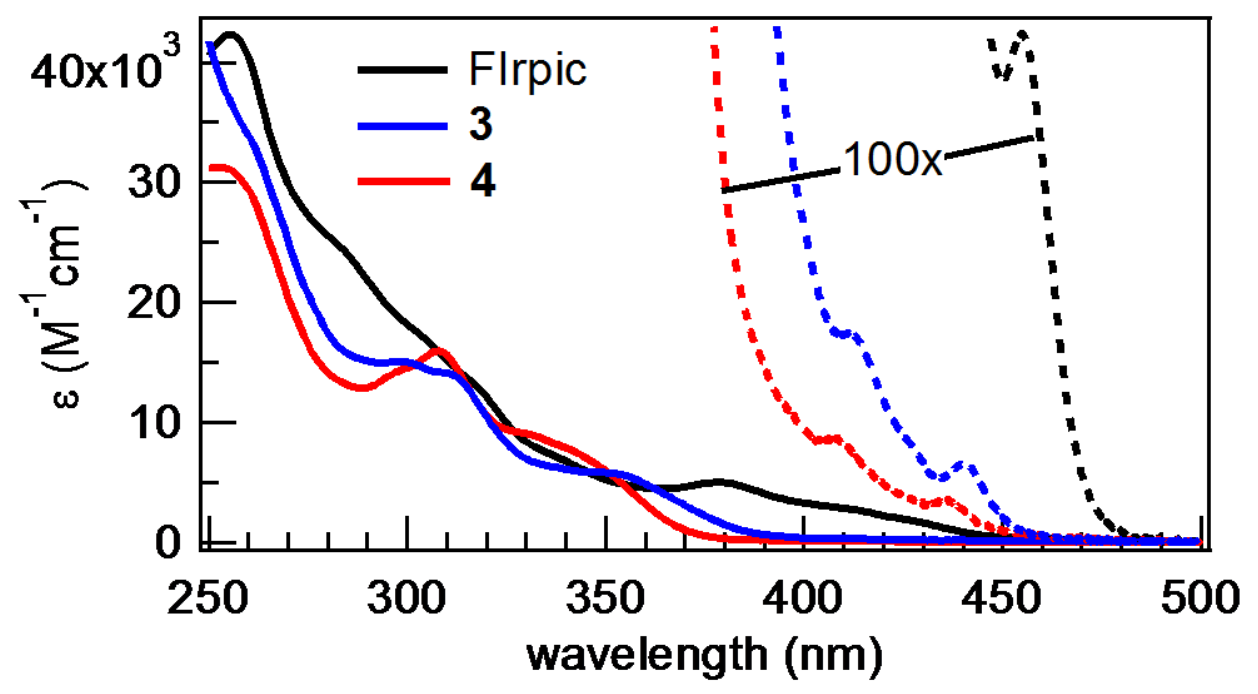

Figure 6. UV-visible absorption spectra of the three iridium complexes in $\mathrm{CH}_{2} \mathrm{Cl}_{2}$ solution. Spectra were acquired with $3 \times 10^{-5} \mathrm{M}$ solutions (left, solid lines) and $3 \times 10^{-4} \mathrm{M}$ solutions (right, dashed lines). The spectra acquired with $3 \times 10^{-4} \mathrm{M}$ solutions were additionally scaled by $10 \mathrm{x}$ in order to show the weak ${ }^{1}$ MLCT and ${ }^{3}$ MLCT bands.

The phosphorescence decays, shown in Figure 7, measured of dilute, degassed solutions ( $3 \times 10^{-5} \mathrm{M}$ in $\mathrm{CH}_{2} \mathrm{Cl}_{2}$ ) for all three compounds can be fit to a single exponentials with microsecond decay times, as typical for emission from a triplet excited state. As reported for other $\mathrm{CN}$-substituted complexes, they decays are relatively slow, and quantum yields high. For example, Chin et al. reported an iridium complex with two CN ligands, offering PL QY $=0.79$ and decay of $2.6 \mu$ s. $^{16}$ 


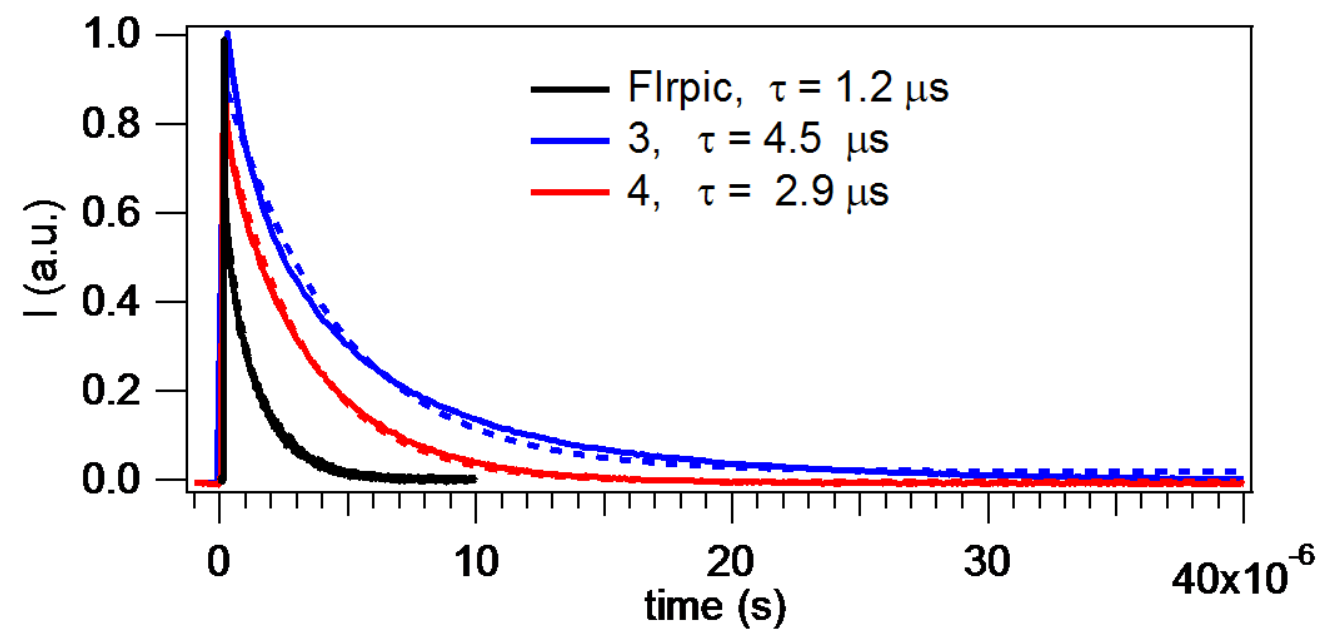

Figure 7. Phosphorescence of the three iridium complexes, acquired with $10^{-5} \mathrm{M}$ solutions in degassed $\mathrm{CH}_{2} \mathrm{Cl}_{2}$ solution. Decays were acquired using $266 \mathrm{~nm}, 20 \mathrm{~ns}$ laser pulses, and exhibit single exponential decays.

Photoluminescence spectra shown in Figure 8 reveal significantly blue-shifted spectra for $\mathbf{3}$ and $\mathbf{4}$, compared to FIrpic. As expected from the absorption spectra, the phosphite compound 4 is blue-shifted from the phosphine compound 3 . Table 3 shows that the phosphorescence quantum yields for $\mathbf{3}$ and $\mathbf{4}$ are high, about $60 \%$, and their measured decay times, 4.5 and $2.9 \mu \mathrm{s}$, respectively, are longer than that measured for FIrpic, at $1.2 \mu \mathrm{s}$. The radiative and non-radiative rates calculated for $\mathbf{3}$ and $\mathbf{4}$ are slower than those for FIrpic.

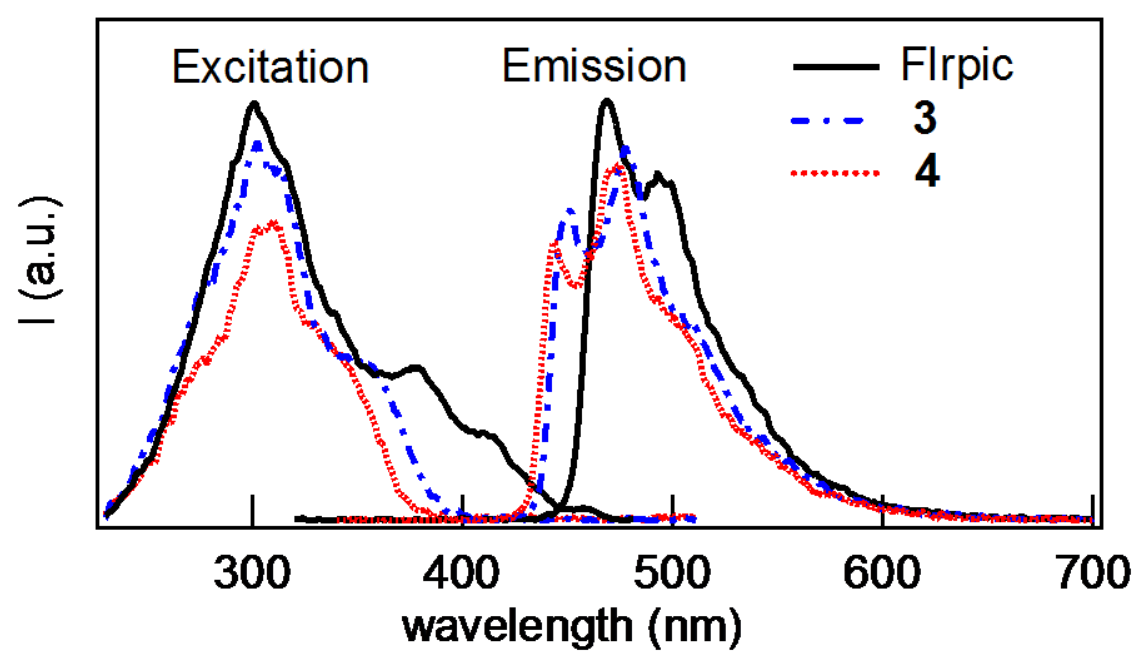

Figure 8. Excitation $\left(\lambda_{\mathrm{em}}=520 \mathrm{~nm}\right)$ and photoluminescence $\left(\lambda_{\mathrm{ex}}=310 \mathrm{~nm}\right)$ emission spectra acquired with $10^{-5} \mathrm{M}$ solutions in $\mathrm{CH}_{2} \mathrm{Cl}_{2}$ of the three iridium compounds show the blue shifted emission of $\mathbf{3}$ and $\mathbf{4}$, compared to FIrpic. 
The CIE coordinates for the new iridium complexes were calculated to be $(x=0.16, y$ $=0.24)$ and $(\mathrm{x}=0.16, \mathrm{y}=0.21)$ for $\mathbf{3}$ and $\mathbf{4}$, respectively. These values indicate considerably bluer emission compared to FIrpic $(x=0.16, y=0.33)$, and they approach the desirable "true blue" emission, in the CIE coordinate range ( $x<0.2, y<0.2)$, as illustrated in Figure 9. While blue emission and high efficiency are promising, the higher-lying $\mathrm{T}_{1}$ states for 3 and $\mathbf{4}$ compared to FIrpic would require a matrix with an even higher lying $\mathrm{T}_{1}$ state, such as $\mathrm{mCP}$, in order to achieve good efficiency in an OLED.

Table 2. Absorption peaks ( $\lambda_{\max }$ for each feature) and their extinction coefficients for the three iridium compounds in $\mathrm{CH}_{2} \mathrm{Cl}_{2}$ solution. Absorption spectra acquired with $3 \times 10^{-4} \mathrm{M}$ concentration solutions.

\begin{tabular}{|l|c|c|c|c|c|c|}
\hline & $\begin{array}{c}\lambda_{1}(\mathrm{~nm}) ; \varepsilon_{1} \\
\left(\mathrm{M}^{-1} \mathrm{~cm}^{-1}\right)\end{array}$ & $\begin{array}{c}\lambda_{2}(\mathrm{~nm}), \varepsilon_{2} \\
\left(\mathrm{M}^{-1} \mathrm{~cm}^{-1}\right)\end{array}$ & $\begin{array}{c}\lambda_{3}(\mathrm{~nm}), \varepsilon_{3} \\
\left(\mathrm{M}^{-1} \mathrm{~cm}^{-1}\right)\end{array}$ & $\begin{array}{c}\lambda_{4}(\mathrm{~nm}) ; \varepsilon_{4} \\
\left(\mathrm{M}^{-1} \mathrm{~cm}^{-1}\right)\end{array}$ & $\begin{array}{c}\lambda_{5}(\mathrm{~nm}), \varepsilon_{5} \\
\left(\mathrm{M}^{-1} \mathrm{~cm}^{-1}\right)\end{array}$ & $\begin{array}{c}\lambda_{6}(\mathrm{~nm}), \varepsilon_{6} \\
\left(\mathrm{M}^{-1} \mathrm{~cm}^{-1}\right)\end{array}$ \\
\hline $\mathbf{3}$ & $255 ;$ & $298 ;$ & $312 ;$ & $355 ;$ & $413 ;$ & $441 ;$ \\
& 37,050 & 15,100 & 13,900 & 5560 & 170 & 65 \\
\hline $\mathbf{4}$ & $255 ;$ & $296 ;$ & $308 ;$ & $345 ;$ & $408 ;$ & $436 ;$ \\
& 31,100 & 14,000 & 16,000 & 7060 & 85 & 35 \\
\hline FIrpic & $255 ;$ & $309 ;$ & $320 ;$ & $339 ;$ & $379 ;$ & $455 ;$ \\
& 42,350 & 15,900 & 12,100 & 6,900 & 4,970 & 430 \\
\hline
\end{tabular}

Table 3. Photophysical properties of the three iridium complexes in $\mathrm{CH}_{2} \mathrm{Cl}_{2}$ solution. Quantum yields were acquired with $3 \times 10^{-5} \mathrm{M}$ concentration solutions, with FIrpic as a standard, per reference 8, and corrected for spectral sensitivity. Phosphorescence decays were acquired with the same dilute solutions and calculations of radiative rate constant, $\mathrm{k}_{\mathrm{r}}$ $=\Phi_{\mathrm{P}} / \tau_{\mathrm{p}}$ and $\mathrm{k}_{\mathrm{nr}}=\left(1-\Phi_{\mathrm{P}}\right) / \tau_{\mathrm{p}}$ are calculated from the measured quantum yields and decays. The lowest triplet energy, $\mathrm{T}_{1}$, was estimated from the absorption spectra shown in Figure 6.

\begin{tabular}{|l|c|c|c|c|c|c|}
\hline & $\Phi_{\mathrm{P}}$ & $\tau_{\mathrm{P}}(\mu \mathrm{s})$ & $\mathrm{k}_{\mathrm{r}}\left(\mathrm{s}^{-1} \times 10^{5}\right)$ & $\mathrm{k}_{\mathrm{nr}}\left(\mathrm{s}^{-1} \times 10^{5}\right)$ & $\mathrm{PL}, \lambda_{\max }(\mathrm{nm})$ & $\mathrm{T}_{1}(\mathrm{eV})$ \\
\hline $\mathbf{3}$ & $0.66 \pm 0.15$ & $4.5 \pm 0.5$ & $1.5 \pm 0.4$ & $0.8 \pm 0.3$ & 451,478 & 2.81 \\
\hline $\mathbf{4}$ & $0.65 \pm 0.15$ & $2.9 \pm 0.3$ & $2.2 \pm 0.6$ & $1.2 \pm 0.5$ & 443,471 & 2.84 \\
\hline FIrpic & $0.80 \pm 0.2^{\mathrm{a}}$ & $1.2 \pm 0.1$ & $6.7 \pm 1.8$ & $1.7 \pm 0.7$ & 468,493 & 2.73 \\
\hline
\end{tabular}

aSee ref. 8. 


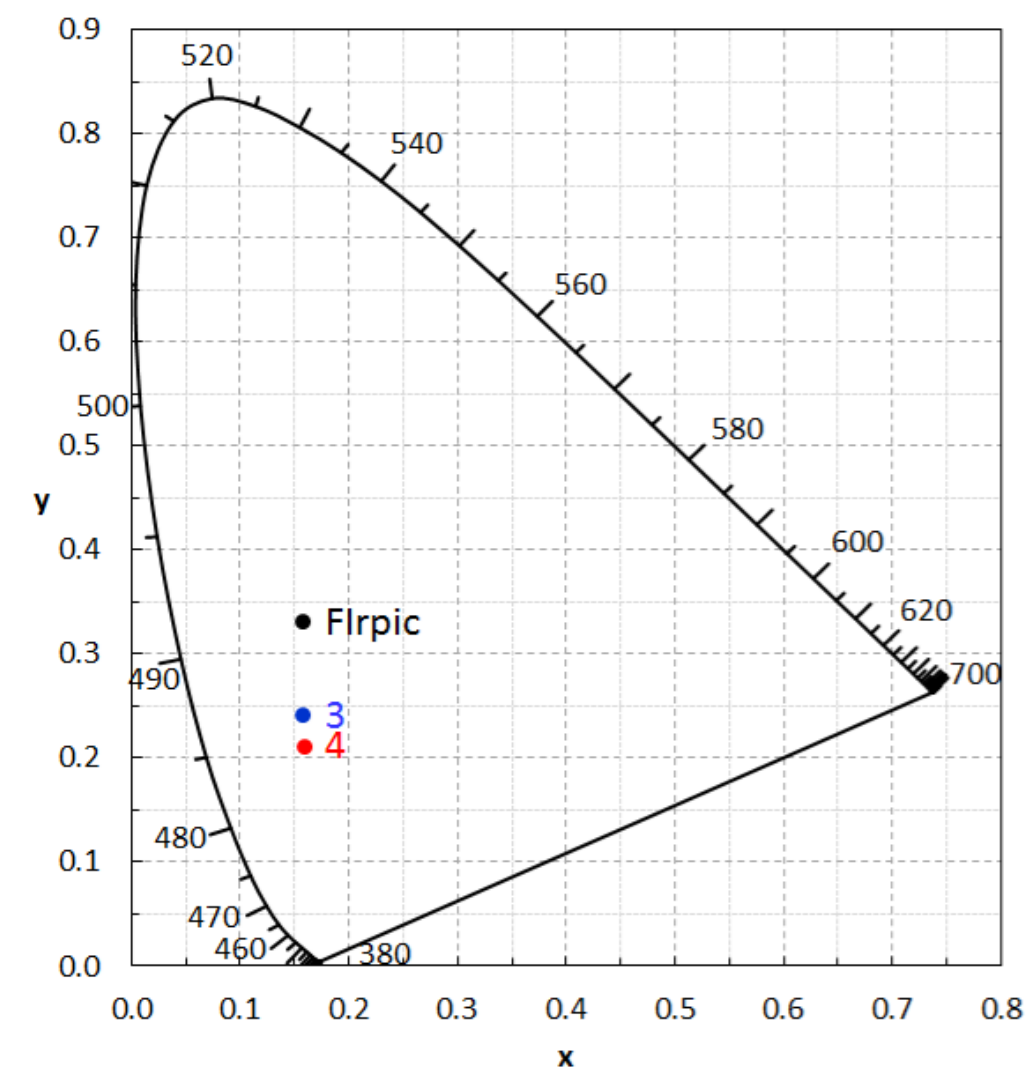

Figure 9. Calculated CIE coordinates for $\mathbf{3}$ and $\mathbf{4}$, compared to FIrpic.

\section{Conclusions}

A series of bis-cyclometallated iridium phosphine and phosphite complexes has been synthesized containing either chloro or cyano ligands. All of the compounds have been characterized by x-ray crystallography; bond length data show that the phosphorus ligands exert a trans effect. The emissive cyano compounds have been studied by optical spectroscopy. We have demonstrated that replacement of the picolinate ligand in FIrpic by the combination of cyano and phosphorus ligands results in a blue shift of the emission with enhanced phosphorescence quantum yield. The blue shift in emission is presumably due to the stabilization of the metal-centered HOMO by the strong field cyano and phosphorus ligands. Greater stabilization and higher energy emission is found for the phosphite ligand relative to the phosphine.

\section{Experimental Section}

Photophysical and Spectroscopy Measurements. Optical absorption spectra were obtained with a Thermo Evolution $220 \mathrm{UV}$-visible spectrometer with $3 \times 10^{-4} \mathrm{M}$ methylene chloride solutions, degassed with Ar in a nitrogen-purged glovebox for 10 minutes prior to sealing into airtight quartz cuvettes. Emission spectra were measured with similarly degassed $3 \times 10^{-5} \mathrm{M}$ solutions with a Thermo Lumina luminescence spectrometer with a 1 
cm path length quartz cuvette, excitation and emission slits of $1 \mathrm{~nm}$, a signal averaging time of $0.2 \mathrm{~s}$, and a scan rate of $300 \mathrm{~nm} /$ minute. Quantum yields were estimated by sensitivity correcting the emission spectra for the PMT and grating efficiency as a function of wavelength, then normalizing the integrated emission spectra to the optical density of each solution at the excitation wavelength, $360 \mathrm{~nm}$. To estimate the quantum yields of 3 and $\mathbf{4}$, their integral light yields were compared to that of FIrpic, and the quantum yield of FIrpic taken to be that reported in the literature. ${ }^{8}$ Phosphorescence lifetime measurements were acquired using a flashlamp-pumped Nd:YAG laser at $266 \mathrm{~nm}$ with $20 \mathrm{~ns}$ pulses. Luminescence was collected with a monochromator, set to the emission wavelength maximum for each compound, coupled to an R928 Hamamatsu PMT and read out by an oscilloscope. For each solution, 25 traces were acquired and averaged to generate the decay curves, which were then fit in Igor Pro, for all decays, to single exponential to obtain the phosphorescence lifetimes. NMR spectra were recorded on a Bruker Avance III 600 $\mathrm{MHz}$ spectrometer.

X-ray Crystallography. Suitable crystals for 1, 2, 3, and 4 were selected for single-crystal diffraction studies. Specimens $\mathbf{1}$ and $\mathbf{4}$ were mounted on a Bruker-AXS VENTURE Diffractometer with a CuK $\alpha \mathrm{I} \mu \mathrm{S}$ microfocus source $(\lambda=1.54178 \AA)$ and PHOTON-100 (CMOS) detector. Specimens $\mathbf{2}$ and $\mathbf{3}$ were mounted on a BRUKER-AXS SMART Diffractometer with a MoK $\alpha$ normal-focus tube source with a pyrolytic graphite monochromator $(\lambda=0.71073 \AA$ ) and an APEX-II (CCD) detector. Unit cell constants were determined initially with the APEX-II software. Final unit cell constants were calculated on large sets of strong reflections from the integration of all data with SAINT. A multi-scan scaling and absorption correction were applied with SADABS based on the Laue class determined for each crystal structure. The crystal structures were solved by direct methods using SHELXL-97 or SHELXT2014. Final least-squares refinements were completed with SHELXL-2014. All non-hydrogen atoms were refined with anisotropic displacements, except for $\mathbf{3}$ (see discussion section). Hydrogen atoms were placed as riding atoms at calculated positions with isotropic displacements relative to respective host atoms. CIF data is available from the Cambridge Crystallographic Data Centre with deposit numbers: 1062173 (compound 1), 1062174 (compound 2), 1062715 (compound 3), and 1062176 (compound 4).

Synthesis. The compounds $\left[(46 \mathrm{dfppy})_{2} \operatorname{Ir}(\mathrm{Cl})\right]_{2}{ }^{19}$ and $(46 \mathrm{dfppy})_{2} \operatorname{Ir}(\mathrm{PPh} 3)(\mathrm{Cl})^{9}$ were prepared by the literature methods.

(46dfppy) ${ }_{2} \operatorname{Ir}\left[\mathbf{P}(\mathbf{O P h})_{3}\right](\mathbf{C l})$ (Compound 2). $2.5 \mathrm{~g}(2.05 \mathrm{mmol})$ of $\left[(\mathrm{dfppy})_{2} \mathrm{Ir}(\mathrm{Cl})\right]_{2}$ and $1.47 \mathrm{~g}(4.7 \mathrm{mmol})$ of $\mathrm{P}(\mathrm{OPh})_{3}$ were combined in $225 \mathrm{~mL}$ nitrogen-purged methylene chloride and the solution was stirred overnight at room temperature under nitrogen. The solvent was removed under vacuum to provide the crude product as a yellow powder. This material was flash chromatographed on a silica column using dichloromethane eluent. The eluted material was concentrated and cooled in the freezer to obtain $3.2 \mathrm{~g}$ of yellow crystalline product (85\% yield). Anal. Calcd for IrC40H27N2ClF4O3P: C, 52.32; H, 2.96; N, 3.05. Found: C, 52.38; H, 3.22; N, 2.99. ${ }^{1} \mathrm{H}$ NMR (600 MHz, $\left.\mathrm{CDCl}_{3}\right)(\mathrm{ppm}): 9.71$ (d, J=5.6 Hz, $1 \mathrm{H}), 9.52$ (d, J=5.7 Hz, 1H), $8.34(\mathrm{~d}, \mathrm{~J}=8.0 \mathrm{~Hz}, 1 \mathrm{H}), 8.13$ (d, J=8.3 Hz, 1H), 7.86 (t, J=7.6 Hz, $1 \mathrm{H}), 7.73(\mathrm{t}, \mathrm{J}=7.6 \mathrm{~Hz}, 1 \mathrm{H}), 7.13(\mathrm{~m}, 7 \mathrm{H}), 7.05(\mathrm{~m}, 3 \mathrm{H}), 6.98(\mathrm{t}, \mathrm{J}=6.6 \mathrm{~Hz}, 1 \mathrm{H}), 6.78(\mathrm{~m}, 6 \mathrm{H})$, 6.39 (t, J=10.8 Hz, 1H), 6.32 (t, J=10.3 Hz, 1H), 5.67 (d, J= 8.5 Hz, 1H), 5.24 (t, J=9.1 Hz, 1H). 
${ }^{19} \mathrm{~F}$ NMR (564 MHz, $\mathrm{CDCl}_{3}$ ) (ppm): -107.16 (quintet, J=9.7 Hz, 1F), -107.56 (q, J=9.0 Hz, 1F), -109.52 (q, J=11.9 Hz, 1F), -110.65 (t, J=11.1 Hz, 1F).

(46dfppy) $)_{2} \operatorname{Ir}\left(\mathrm{PPh}_{3}\right)(\mathrm{CN})$ (Compound 3). $1.43 \mathrm{~g}(1.64 \mathrm{mmol})$ of (dfppy $)_{2} \operatorname{Ir}\left(\mathrm{PPh}_{3}\right)(\mathrm{Cl})$ was dissolved in $150 \mathrm{~mL}$ methanol and heated to $50{ }^{\circ} \mathrm{C}$. Silver trifluoroacetate was added and the resultant silver chloride was filtered off on a celite pad. Potassium cyanide $(0.20 \mathrm{~g}, 3.08$ mmol) dissolved in $20 \mathrm{~mL}$ of methanol was added to the filtrate and this solution was refluxed for 1 hour under nitrogen. The reaction mixture was concentrated and cooled in the freezer. The resultant yellow crystals were collected and washed with cold methanol to yield $0.75 \mathrm{~g}$ of product. A second crop of $0.40 \mathrm{~g}$ crystals was collected by concentrating and cooling the filtrate and washings. This second batch showed NMR results identical to the first batch for a combined yield of 81\%. Anal. Calcd for IrC41H27N3F4P: C, 57.20; H, 3.16; N, 4.88; F, 8.83; P, 3.60. Found: C, 56.0; H, 2.87; N, 5.07; F, 8.92; P, 3.40. ${ }^{1} \mathrm{H} \mathrm{NMR} \mathrm{(600} \mathrm{MHz,}$ $\left.\mathrm{CDCl}_{3}\right)(\mathrm{ppm}): 9.07(\mathrm{~d}, \mathrm{~J}=5.7 \mathrm{~Hz}, 1 \mathrm{H}), 8.67(\mathrm{~d}, \mathrm{~J}=5.6 \mathrm{~Hz}, 1 \mathrm{H}), 8.37(\mathrm{~d}, \mathrm{~J}=6.5 \mathrm{~Hz}, 1 \mathrm{H}), 8.06(\mathrm{~d}$, $\mathrm{J}=8.4 \mathrm{~Hz}, 1 \mathrm{H}), 7.81(\mathrm{t}, \mathrm{J}=7.7 \mathrm{~Hz}, 1 \mathrm{H}), 7.60(\mathrm{t}, \mathrm{J}=7.7 \mathrm{~Hz}, 1 \mathrm{H}), 7.33(\mathrm{~m}, 9 \mathrm{H}), 7.22(\mathrm{~m}, 6 \mathrm{H}), 6.79$ $(\mathrm{t}, \mathrm{J}=6.3 \mathrm{~Hz}, 1 \mathrm{H}), 6.69(\mathrm{t}, \mathrm{J}=6.3 \mathrm{~Hz}, 1 \mathrm{H}), 6.41(\mathrm{~m}, 2 \mathrm{H}), 5.38(\mathrm{~m}, 2 \mathrm{H}) .{ }^{19} \mathrm{~F} \mathrm{NMR}(564 \mathrm{MHz}$, $\mathrm{CDCl}_{3}$ ) (ppm): -106.98 (quintet, J=8.4 Hz, 1F), -108.07 (q, J=8.9 Hz, 1F), -109.73 (m, 2F).

(46dfppy) $\left.{ }_{2} \operatorname{Ir}[\mathbf{P ( O P h})_{3}\right](\mathbf{C N})$ (Compound 4). The same procedure as described for (46dfppy) ${ }_{2} \operatorname{Ir}\left(\mathrm{PPh}_{3}\right)(\mathrm{CN})$ was followed, giving yellow crystals in $65 \%$ yield. Anal. Calcd for IrC41H27N3F403P: C, 54.18; H, 2.99; N, 4.62. Found: C, 53.52; H, 3.03; N, 4.68. ${ }^{1} \mathrm{H}$ NMR $\left(600 \mathrm{MHz}, \mathrm{CDCl}_{3}\right)(\mathrm{ppm}): 9.50(\mathrm{~d}, \mathrm{~J}=5.6 \mathrm{~Hz}, 1 \mathrm{H}), 9.40(\mathrm{~d}, \mathrm{~J}=5.7 \mathrm{~Hz}, 1 \mathrm{H}), 8.35$ (d, J=7.9 Hz, $1 \mathrm{H}), 8.17(\mathrm{~d}, \mathrm{~J}=8.6 \mathrm{~Hz}, 1 \mathrm{H}), 7.88(\mathrm{t}, \mathrm{J}=7.8 \mathrm{~Hz}, 1 \mathrm{H}), 7.76(\mathrm{t}, \mathrm{J}=7.8 \mathrm{~Hz}, 1 \mathrm{H}), 7.15(\mathrm{~m}, 7 \mathrm{H}), 7.07$ $(\mathrm{m}, 3 \mathrm{H}), 6.91(\mathrm{t}, \mathrm{J}=6.6 \mathrm{~Hz}, 1 \mathrm{H}), 6.83(\mathrm{~m}, 6 \mathrm{H}), 6.41(\mathrm{t}, \mathrm{J}=10.6 \mathrm{~Hz}, 1 \mathrm{H}), 6.30(\mathrm{t}, \mathrm{J}=10.1 \mathrm{~Hz}, 1 \mathrm{H})$, $5.56(\mathrm{~d}, \mathrm{~J}=7.4 \mathrm{~Hz}, 1 \mathrm{H}), 5.30$ (t, J=7.8 Hz, 1H). ${ }^{19} \mathrm{~F}$ NMR (564 MHz, CDCl $)$ (ppm): -107.10 (quintet, J=9.7 Hz, 1F), -107.60 (q, J=8.9 Hz, 1F), -109.46 (q, J=11.9 Hz, 1F), -110.07 (t, $\mathrm{J}=10.9 \mathrm{~Hz}, 1 \mathrm{~F})$.

\section{Acknowledgements}

We thank the X-Ray Crystallographic Laboratory, LeClaire-Dow Instrumentation Facility, Department of Chemistry, University of Minnesota for its contribution. The authors would like to acknowledge Ms. Laura Clouston and the CHEM5755 X-Ray Crystallography for the assistance in collecting single crystal diffraction data on sample 1. The Bruker-AXS D8 Venture diffractometer was purchased through a grant from NSF/MRI (\#1229400) and the University of Minnesota. We appreciate the help from Alexander Drobshoff in acquiring the phosphorescence lifetimes, and the use of a CIE calculator, written by Stephen A. Payne. This work was funded by the National Nuclear Security Administration, Defense Nuclear Nonproliferation Research and Development Office of the U.S. Department of Energy under Contract DE-AC03-76SF00098, and was performed under the auspices of the U. S. Department of Energy by Lawrence Livermore National Laboratory under Contract DEAC52-07NA27344. Release number is LLNL-JRNL-669760.

\section{Appendix A. Supplementary data}


Structural drawings with complete atom labeling and bond length/bond angle data for 1-4 can be found at: 


\section{References}

[1] L. Flamigni, A. Barbieri, C. Sabatini, B. Ventura, F. Barigelletti, Top. Curr. Chem., 281 (2007) 143-203.

[2] J.H. Seo, S.C. Lee, Y.K. Kim, Y.S. Kim, Thin Solid Films, 517 (2009) 4119-4121.

[3] Y. Zhang, Y. Xu, Q. Niu, J. Peng, W. Zang, X. Zhu, Y. Cao, J. Mater. Chem., 17 (2007) 9921001.

[4] S. Lamansky, P. Djurovich, D. Murphy, F. Abdel-Razzaq, R. Kwong, I. Tsyba, M. Bortz, R. Bau, M.E. Thompson, Inorg. Chem., 40 (2001) 1704-1711.

[5] Y.-M. Wang, F. Teng, L.-H. Gan, H.-M. Liu, X.-H. Zhang, W.-F. Fu, Y.-S. Wang, X.-R. Xu, J. Phys. Chem. C, 112 (2008) 4743-4747.

[6] L. Ziao, Z. Chen, B. Qu, J. Luo, Sh. Kong, Q. Gong, J. Kido, Adv. Mater., 23, (2011) 926-952.

[7] B.L. Rupert, N.J. Cherepy, B.W. Sturm, R.D. Sanner, S.A. Payne, Europhysics Lett., 97, (2012) 22002.

[8] E. Baranoff and B.F.E. Curchod, Dalton Trans. 44 (2015) 8318-8329.

[9] K. Dedian, J. Shi, E. Forsythe, D.C. Morton, P.Y. Zavalij, Inorg. Chem., 46, (2007) 16031611.

[10] X. Shen, X.-H. Hu, F.-L. Wang, F. Sun, Y.-Q. Yang, Y. Xu, S. Chen, D.-R. Zhu, Inorg. Chem Commun. 13 (2010) 1096-1099.

[11] C.-H. Hsieh, F.-I. Wu, C.-H. Fan, M.-J. Huand, K.-Y. Lu, P.-Y. Chou, Y.-H. Ou Yang, S.-H. Wu, I.-C. Chen, S.-H. Chou, K.-T. Wong, C.-H. Cheng, Chem. Eur. J., 17, (2011), 9180-9187.

[12] B.D. Stringer, L.M. Quan, P.J. Barnard, D.J.D. Wilson, C.F. Hogan, Organometallics 33, (2014) 4860-4872.

[13] J.-B. Kim, S.-H. Han, K. Yang, S.-K. Kwon, J.-J. Kim, Y.-H. Kim, Chem. Commun., 51 (2015), 58.

[14] Md. K. Nazeeruddin, R. Humphry-Baker, D. Berner, S. Rivier, L. Zuppiroli, M. Graetzel, J. Am. Chem. Soc. 125 (2003) 8790-8797.

[15] Y.-Y. Lyu, Y. Byun, O. Kwon, E. Han, W.S. Jeon, R. R. Das, K. Char, J. Phys. Chem. B 110 (2006) 10303-10314.

[16] C.S. Chin, M.-S. Eum, S.Y. Kim, C. Kim, S.K. Kang, Eur. J. Inorg. Chem. (2007) 372-375. 
[17] M.-S. Eum, C.S. Chin, S.Y. Kim, C. Kim, S.K. Kang, N.H. Hur, J. H. Seo, G.Y. Kim and Y.K. Kim, Inorg. Chem. 47 (2008) 6289-6295.

[18] E. Baranoff, I. Jung, R. Scopelliti, E. Solari, M. Graetzel, Md. K. Nazeeruddin, Dalton Trans., 40 (2011), 6860-6867.

[19] A.B. Tamayo, B.D. Alleyne, P.I. Djurovich, S. Lemansky, I. Tsyba, N.N. Ho, R. Bau, M.E. Thompson, J. Amer. Chem. Soc. 125 (2003) 7377-7387.

[20] J. Brooks, Y. Babayan, S. Lamansky, P.I. Djurovich, I. Tsyba, R. Bau, M.E. Thompson, Inorg. Chem. 41 (2002) 3055-3066.

[21] X. Shen, H. Yang, X.-H. Hu, Y. Xu, F.-L. Wang, S. Chen, D.-R. Zhu, Inorg. Chem. Commun. 12 (2009) 785-788.

[22] C.-L. Lee, R.R. Das, J.-J. Kim, Curr. Appl. Phys. 5 (2005) 309-313.

[23] C.A. Tolman, Chem. Rev. 77 (1977) 313-348.

[24] Y. You, S.Y. Park, J. Amer. Chem. Soc. 127 (2005) 12438-12439. 


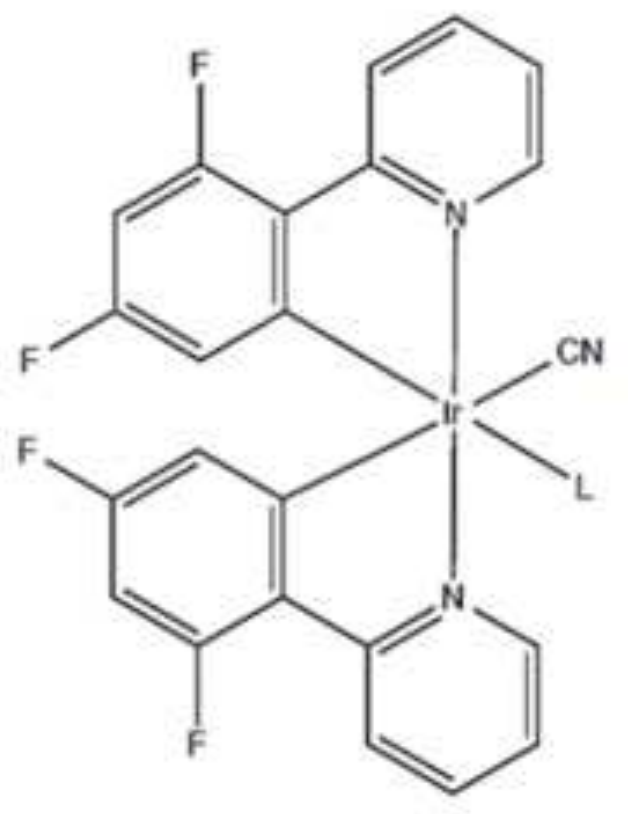

$3\left[\mathrm{~L}=\mathrm{PPh}_{3}\right]$

$\left.4 \mathrm{~L}=\mathrm{P}(\mathrm{OPh})_{3}\right]$

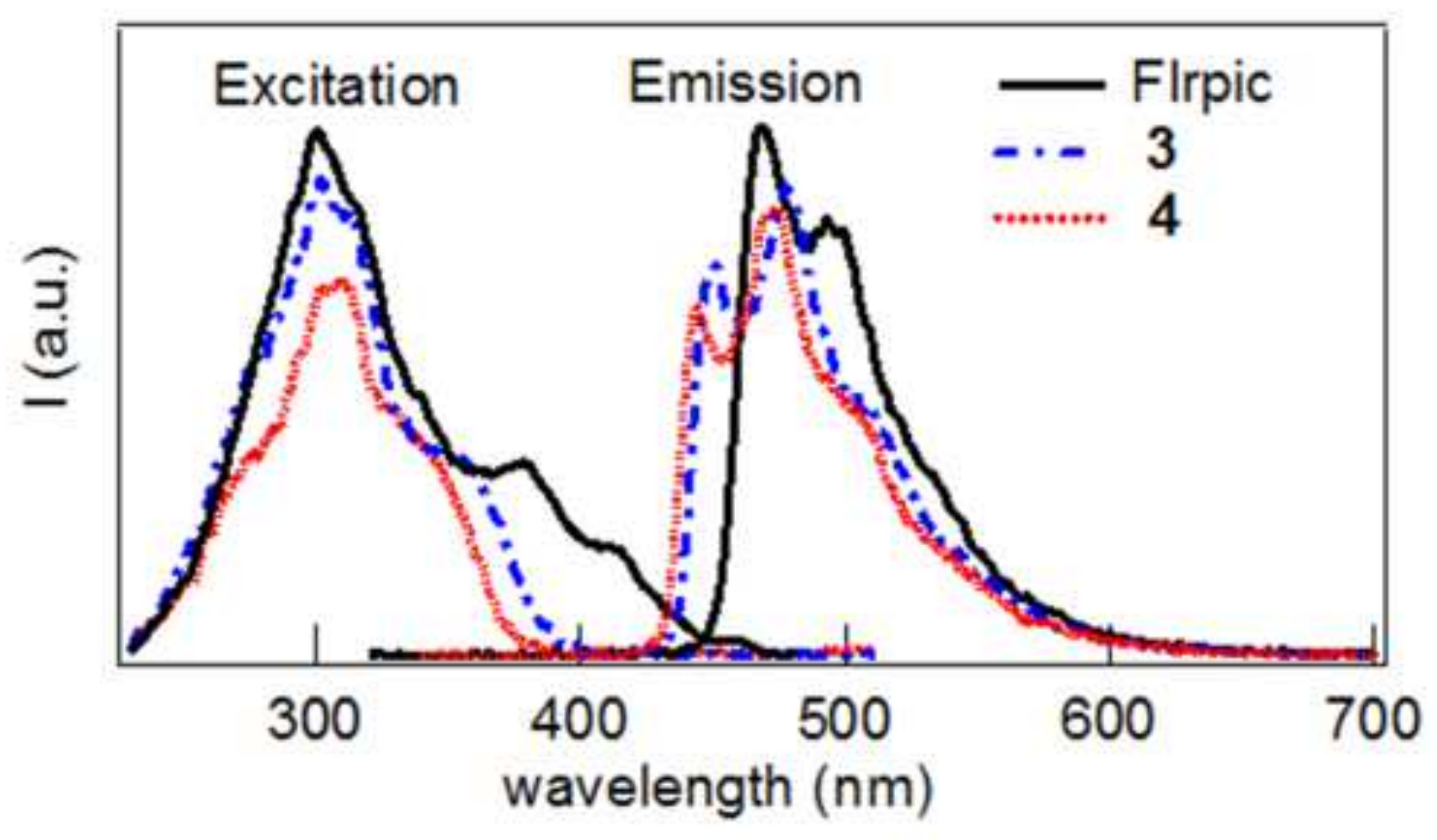

